\title{
ANALISIS ISI IKLAN TELEVISI DI INDONESIA
}

\author{
Moondore Madalina Ali
}

Psychology Department, Faculty of Humanities, BINUS University

Jln. Kemanggisan Ilir III No.45, Kemanggisan - Palmerah, Jakarta 11480

Mali@binus.edu

\begin{abstract}
There are no television channels especially for children in Indonesia. Children's programmes usually air early in the morning or in the afternoon. Most children watch television during Saturday and Sunday where most of them do not have to go to school. Children could watch any programmes airing during those times. There were not many content analysis researches looking at advertiments aired in television before in Indonesia. Therefore, this study looked at advertisements shown on Saturday and Sunday by using quantitative method. Quantitative method used was content analysis. Four private channels were chosen with a total 120 hours of television program recorded on Saturday and Sunday. This study showed that 37 out of 120 hours of television were advertisement with 6898 advertisements (promotion and products). Children in Indonesia were exposed to many advertisements on television on Saturday and Sunday.
\end{abstract}

Keywords: private television channels, television advertisement, content analysis, weekend television program

\begin{abstract}
ABSTRAK
Di Indonesia tidak ada stasiun televisi yang khusus ditujukan untuk anak. Program anak-anak biasanya disiarkan pada pagi hari atau sore hari. Kebanyakan anak menonton televisi pada Sabtu dan Minggu, ketika mereka tidak perlu pergi ke sekolah. Anak-anak dapat menonton segala jenis program yang ditayangkan pada waktu-waktu tersebut. Penelitian sebelumnya mengenai analisis isi iklan televisi di Indonesia belum banyak. Penelitian ini ingin melihat iklan yang ditayangkan pada Sabtu dan Minggu dengan menggunakan metode kuantitatif. Metode kuantitatif yang digunakan adalah metode analisis konten. Empat stasiun televisi swasta dipilih dengan total 120 jam program televisi yang direkam pada Sabtu dan Minggu. Penelitian ini menemukan 37 dari 120 jam program televisi adalah iklan dengan 6898 iklan (promosi maupun produk). Anak-anak di Indonesia terekspos dengan berbagai banyak iklan di televisi pada Sabtu dan Minggu
\end{abstract}

Kata kunci: televisi swasta, iklan televisi, analisis isi, program televisi akhir pekan 


\section{PENDAHULUAN}

Anak-anak menghabiskan waktu mereka di luar sekolah dengan menonton televisi yang di dalamnya terdapat berbagai macam siaran; antara lain: berita, sinetron, kartun, dan termasuk iklan. Banyaknya anak yang menonton televisi digunakan oleh perusahaan periklanan untuk mengiklankan produk-produk mereka di televisi (Kunkel et al., 2004). Di Amerika Serikat pada 1999 anak-anak menonton rata-rata 20.000 iklan televisi setiap tahun dan diperkirakan anak-anak di Amerika Serikat melihat lebih dari 40.000 iklan per tahun (Kunkel, 2001). Sementara di Inggris, anak-anak yang menonton sekitar 18.000 iklan setiap tahunnya (Carvel, 2000).

Untuk memahami iklan di televisi anak-anak memerlukan dua keterampilan. Keterampilan pertama adalah kemampuan untuk membedakan antara iklan dan program, dan yang kedua adalah kemampuan untuk memahami maksud dari persuasif iklan (Kunkel et al., 2004). Robertson dan Rossiter (1974) menambahkan anak dapat dikatakan memahami tentang iklan jika mereka bisa mencapai lima kriteria berikut: kemampuan untuk membedakan antara iklan dan program, mengetahui sumber iklan, pengetahuan dari target audiens untuk setiap iklan, pemahaman simbolis sifat iklan, dan kemampuan untuk mengkritik dan mengevaluasi produk yang ditampilkan dalam iklan.

Teori perkembangan dari Piaget sering digunakan untuk menjelaskan tentang perkembangan anak mengenai iklan. Ketika anak-anak masuk ke tahap perkembangan praoperasional, mereka mulai dapat membedakan iklan dari program (Gunter et al., 2005), dan mereka melihat iklan sebagai sesuatu yang menghibur (John, 1999). Anak-anak pada tahap operasional konkret dan formal mulai memahami iklan. Lawler dan Prothero (2002) menyatakan bahwa anak-anak dalam tahap operasional konkret (7 sampai 11 tahun) mulai berpikir dan mulai mengevaluasi pesan dalam iklan. Namun pengetahuan tentang taktik iklan dan daya tarik produk umumnya tidak muncul sampai usia dua belas, dengan dimulainya tahap operasional formal (John, 1999).

Dampak dari iklan adalah meningkatnya obesitas di kalangan anak-anak (Kunkel et al., 2004). Beberapa penelitian di luar menunjukkan kausalitas antara iklan makanan dengan obesitas. Halford et al (2003) meminta anak-anak untuk menonton iklan makanan dan iklan bukan makanan. Mereka menemukan anak-anak makan lebih banyak setelah mereka menonton iklan makanan dan anak-anak yang mempunyai kelebihan berat badan di dalam penelitian tersebut ingat tentang iklan makanan yang ditayangkan. Penelitian selanjutnya dilakukan oleh Gorn and Goldberg (1982) yang meneliti anak berusia 5-8 tahun selama dua minggu. Mereka menemukan ketika anak-anak diekpos dengan iklan jus jeruk, mereka akan lebih banyak meminum jus jeruk tersebut. Namun ketika anak-anak diekspos dengan iklan permen, mereka minum jus jeruk lebih sedikit. Kedua contoh penelitian ini menunjukkan bahwa iklan memengaruhi anak-anak tentang pilihan dan perilaku.

Dampak negatif lain dari iklan adalah anak menjadi materialistis (Kunkel et al., 2004). Selain iklan makanan yang ditayangkan di televisi, anak-anak juga menonton iklan mainan dan yang lainnya. Penelitian sebelumnya menunjukkan makin sering anak menonton iklan di televisi, mereka akan menjadi materialistis. Buijzen dan Valkenburg (2003) meminta anak berumur 8 sampai dengan 12 tahun untuk mengisi kuesioner dan menemukan anak yang menonton lebih banyak iklan televisi menjadi lebih materialistis daripada anak yang tidak menonton banyak iklan. Nairn, Ormrod, and Bottomley (2007) juga menemukan hal yang serupa. Mereka menemukan korelasi positif antara banyaknya waktu anak-anak terekspos televisi dan perilaku materialistis pada anak. Anak yang terekspos televisi dan komputer akan mempunyai perilaku materialitis.

Sama halnya di Indonesia, anak-anak di Indonesia melihat banyak iklan di televisi. Namun di Indonesia, tidak ada undang-undang yang spesifik untuk mengatur iklan-iklan yang ditujuan untuk elaksanaan penyiaran niaga periklanan untuk anak diatur dalam Bab IV Pasal 42 ayat 6 UndangUndang No. 32 tahun 2002, yang menyatakan bahwa iklan yang disiarkan di dalam program anakanak harus disesuaikan dengan standar siaran televisi untuk anak-anak. Dengan peraturan yang tidak 
optimal, anak-anak di Indonesia dapat menonton tidak hanya iklan yang ditargetkan untuk mereka tetapi juga iklan yang ditargetkan untuk populasi lainnya.

Penelitian tentang analisis isi iklan televisi telah banyak dilakukan di Amerika dan Inggris; sedangkan di Indonesia tidak banyak penelitian mengenai konten iklan televisi. Tujuan dari penelitian ini adalah mengobservasi banyaknya iklan yang ditayangkan di televisi, macam-macam iklan, durasi iklan, dan produk-produk yang diiklankan di televisi.

\section{METODE}

Metode yang digunakan dalam penelitian ini adalah metode kuantitatif dengan menggunakan analisis isi (konten analisis). Analisis isi kuantitatif adalah penelitian ilmiah yang bertujuan untuk menganalisis gambaran isi secara sistematis (Eriyanto, 2011). Populasi dalam penelitan ini adalah iklan-iklan yang ditayangkan di stasiun-statiun televisi Indonesia. Sampel pada penelitian ini adalah empat stasiun televisi swasta di Indonesia. Teknik pengambilan menggunakan purposive sampling. Purposive sampling adalah pengambilan data yang dilakukan sesuai dengan karakteristik yang telah ditentukan oleh peneliti. Karakteristik yang ditentukan oleh peneliti adalah stasiun televisi swasta, stasiun televisi yang menyiarkan program anak-anak.

Teknik pengumpulan data dilakukan dengan membuat rekaman empat stasiun televisi swasta di Jakarta yang telah ditentukan oleh peneliti dari pukul 06:00 sampai dengan pukul 21:00. Instrumen yang digunakan dalam penelitian ini adalah check list. Peneliti membuat beberapa daftar yang diobservasi ketika melihat iklan-iklan yang direkam sebelumnya. Pengolahan data dalam penelitian ini menggunakan deskriptif dengan memaparkan frekuensi, mean, dan jenis iklan yang ditayangkan di empat stasiun televisi tersebut.

\section{HASIL DAN PEMBAHASAN}

Seratus dua puluh jam siaran televisi direkam dari empat stasiun swasta. Berikut ini adalah hasil analisis isi yang dilihat dari durasi iklan, jumlah iklan yang ditayangkan pada Sabtu dan Minggu, jumlah iklan produk dan iklan promosi, jenis iklan di setiap stasiun televisi swasta, dan frekuensi penayangan.

\section{Durasi Iklan yang Ditayangkan pada Sabtu dan Minggu}

Dari 15 jam yang direkam pada Sabtu dan 15 jam pada Minggu (Tabel 1), didapatkan bahwa RCTI menyiarkan iklan 4 jam 35 menit pada Sabtu dan 4 jam 21 menit pada Minggu. MNCTV menyiarkan iklan selama 5 jam 17 menit pada Sabtu dan 4 jam 33 menit pada Minggu. Indosiar menyiarkan iklan selama 4 jam 25 menit pada Sabtu and 4 jam 39 menit pada Minggu. Sedangkan SCTV menyiarkan iklan selama 4 jam 13 menit pada Sabtu dan 4 jam 26 menit pada Minggu.

Tabel 1 Durasi Iklan yang Ditayangkan pada Empat Televisi Swasta di Indonesia

\begin{tabular}{lcc}
\hline & Sabtu & Minggu \\
\hline RCTI & $4: 35$ & $4: 21$ \\
MNCTV & $5: 17$ & $4: 33$ \\
INDOSIAR & $4: 25$ & $4: 39$ \\
SCTV & $4: 13$ & $4: 26$ \\
\hline
\end{tabular}




\section{Jumlah Iklan yang Ditayangkan pada Sabtu dan Minggu}

Tabel 2 menampilkan jumlah iklan yang ditayangkan dari pukul 06:00 sampai dengan pukul 21:00 di empat televisi swasta.

Tabel 2 Jumlah Iklan yang Ditayangkan pada Sabtu dan Minggu di Empat Stasiun Televisi

\begin{tabular}{lcc} 
& Sabtu & Minggu \\
\hline RCTI & 944 & 878 \\
MNCTV & 931 & 849 \\
INDOSIAR & 821 & 770 \\
SCTV & 762 & 943 \\
\hline
\end{tabular}

Berdasarkan Tabel 2, RCTI menayangkan 944 iklan pada Sabtu dan 878 pada Minggu. MNCTV menayangkan 931 iklan pada Sabtu dan 849 pada Minggu. INDOSIAR menayangkan 821 iklan pada Sabtu dan 849 iklan pada Minggu. Sedangkan SCTV menayangkan 762 iklan pada Sabtu dan 943 iklan pada Minggu.

\section{Jumlah Iklan Produk dan Promo yang Ditayangkan pada Sabtu dan Minggu}

Tabel 3 menampilkan jumlah iklan produk dan promosi yang disiarkan di empat stasiun televisi. Promosi yang dimaksud dalam hal ini adalah layanan jasa, promosi sebuah program televisi, atau promosi tentang partai politik.

Tabel 3 Jumlah Iklan Produk dan Promosi yang Disiarkan pada Sabtu dan Minggu

\begin{tabular}{lcccc}
\hline & \multicolumn{2}{c}{ Sabtu } & \multicolumn{2}{c}{ Minggu } \\
\hline & Produk & Promosi & Produk & Promosi \\
\hline RCTI & 840 & 104 & 753 & 125 \\
MNCTV & 862 & 69 & 766 & 83 \\
INDOSIAR & 766 & 55 & 701 & 69 \\
SCTV & 712 & 50 & 879 & 64 \\
\hline
\end{tabular}

Berdasarkan Tabel 3, RCTI menyiarkan 840 iklan produk and 104 iklan promosi pada Sabtu dan 753 iklan produk dan 125 iklan promosi pada Minggu. MNCTV menyiarkan 862 iklan produk dan 69 iklan promosi pada Sabtu dan 766 iklan produk and 83 iklan promosi pada Minggu. INDOSIAR menyiarkan 766 iklan produk dan 55 iklan promosi pada Sabtu dan 701 iklan produk dan 69 iklan promosi pada Minggu. SCTV menyiarkan 712 iklan produk dan 50 iklan promosi pada Sabtu dan 879 iklan produk dan 64 iklan promosi pada Minggu. 


\section{Jenis-jenis Iklan Produk dan Frekuensi Iklan Disiarkan di RCTI pada Sabtu}

Berikut adalah tabel jenis iklan dan banyaknya penanyangan di RCTI pada hari Sabtu.

Tabel 4 Jenis-jenis Iklan dan Frekuensi penayangan

di RCTI pada Sabtu

\begin{tabular}{lc}
\hline \multicolumn{1}{c}{ Jenis-jenis Iklan } & $\begin{array}{c}\text { Frekuensi } \\
\text { Penayangan }\end{array}$ \\
\hline Toiletries & 188 \\
Makanan & 182 \\
Minuman & 131 \\
Peralatan rumah tangga & 75 \\
Kesehatan & 33 \\
Susu & 28 \\
Bumbu dapur & 24 \\
Permen & 21 \\
Peralatan Telekomunikasi & 14 \\
Bahan bangunan & 14 \\
Kendaraan & 10 \\
Telekomunikasi & 10 \\
Website & 5 \\
Entertainment & 4 \\
Aplikasi (katok) & 4 \\
Asuransi & 2 \\
Penerbangan & 2 \\
Bank & 1 \\
Peralatan Automotif & 1 \\
\hline \multicolumn{1}{c}{ Total } & 840 \\
\hline
\end{tabular}

Berdasarkan Tabel 4, RCTI menayangkan 188 iklan toiletries (sampo, pasta gigi, sikat gigi, sabun, dll), 182 iklan makanan, 131 iklan minuman, 75 iklan peralatan rumah tangga (pembersih lantai, kaca, dapur, dll), 32 iklan kesehatan (obat, vitamin, minyak kayu putih), 28 iklan susu (baik untuk anak, orang tua, maupun ibu hamil), 24 iklan bumbu dapur (kecap, tepung, dll), 21 iklan permen, 14 iklan peralatan telekomunikasi (handphone, tablet), 14 iklan bahan bangunan (semen dan cat tembok), 10 iklan automotif (mobil dan motor), 10 iklan telekomunikasi (provider xl, simpati, dll), 5 iklan website (berniaga, dll), 4 iklan entertainment (CD lagu), 4 iklan aplikasi, 2 iklan penerbangan, 2 iklan asuransi, 1 iklan bank, and 1 iklan peralatan automotif (pembersih motor). 


\section{Jenis-jenis Iklan Produk dan Frekuensi Iklan Disiarkan di RCTI pada Minggu}

Berikut adalah tabel jenis-jenis iklan dan banyak penayangan di RCTI pada Minggu.

Tabel 5 Jenis-jenis Iklan dan Frekuensi Penayangan di RCTI pada Minggu

\begin{tabular}{lc}
\hline \multicolumn{1}{c}{ Jenis Iklan } & $\begin{array}{c}\text { Frekuensi } \\
\text { Penayangan }\end{array}$ \\
\hline Toiletries & 218 \\
Minuman & 195 \\
Makanan & 123 \\
Peralatan Rumah Tangga & 77 \\
Kesehatan & 45 \\
Susu & 34 \\
Peralatan Automotif & 26 \\
Bumbu dapur & 23 \\
Telekomunikasi & 19 \\
Peralatan Komunikasi & 16 \\
Permen & 13 \\
Bahan bangunan & \\
(semen,cat tembok,pipa) & 13 \\
Automotif & 10 \\
Bank & 5 \\
Supermarket & 5 \\
Elektronik & 4 \\
Entertainment & 4 \\
Digital & 2 \\
Penerbangan & 2 \\
Asuransi & 2 \\
Koran & 2 \\
Website & 1 \\
Aplikasi & Total \\
\hline
\end{tabular}

Berdasarkan Tabel 5, RCTI pada Minggu menayangkan 218 iklan toiletries (sabun, sampo, pasta gigi, dll), 195 iklan minuman, 123 iklan makanan, 77 iklan peralatan rumah tangga, 45 iklan kesehatan, 34 iklan susu, 26 iklan peralatan automotif, 23 iklan bumbu dapur, 19 iklan telekomunikasi, 16 iklan peralatan komunikasi, 13 iklan permen, 13 iklan bangunan, 10 iklan automotif, 5 iklan bank, 5 iklan supermarket (Carrefour, dll), 4 iklan elektronik, 4 iklan entertainment (CD), 2 iklan digital, 2 iklan penerbangan, 2 iklan asuransi, 2 iklan koran, 1 iklan website (berniaga), dan 1 iklan aplikasi (Katok). 


\section{Jenis-jenis Iklan Produk dan Frekuensi Iklan Disiarkan di MNCTV pada Sabtu}

Berikut adalah tabel jenis-jenis iklan dan banyaknya penanyangan di MNCTV pada Sabtu.

Tabel 6 Jenis-jenis Iklan dan Frekuensi Penayangan di MNCTV pada Sabtu

\begin{tabular}{lc}
\hline \multicolumn{1}{c}{ Jenis Iklan } & Frekuensi Penayangan \\
\hline Toiletries & 271 \\
Makanan & 153 \\
Bumbu dapur & 104 \\
Minuman & 100 \\
Peralatan Rumah tangga & 84 \\
Susu & 58 \\
Kesehatan & 41 \\
Peralatan telekomunikasi & 22 \\
Permen & 7 \\
Telekomunikasi & 7 \\
Entertainment & 4 \\
Asuransi & 3 \\
Aplikasi (we chat) & 2 \\
TV berlanganan & 1 \\
Elektronik & 1 \\
\hline \multicolumn{1}{c}{ Total } & 862 \\
\hline
\end{tabular}

Berdasarkan Tabel 6, pada Sabtu MNCTV menayangkan 271 iklan toiletries, 153 iklan makanan, 104 iklan bumbu dapur, 100 iklan minuman, 84 iklan peralatan rumah tangga, 58 iklan susu, 41 iklan kesehatan, 22 iklan peralatan komunikasi, 7 iklan permen, 7 iklan telekomunikasi, 4 iklan entertainment, 3 iklan asuransi, 2 iklan aplikasi (We Chat), 1 iklan TV berlanganan, dan 1 iklan elektronik.

\section{Jenis-jenis Iklan Produk dan Frekuensi Iklan Disiarkan di MNCTV pada Minggu}

Berikut adalah tabel jenis-jenis iklan dan banyaknya penanyangan di MNCTV pada Minggu.

Tabel 7 Jenis-jenis Iklan dan Frekuensi Penayangan di MNCTV pada Minggu

\begin{tabular}{lc}
\hline \multicolumn{1}{c}{ Jenis Iklan } & Frekuensi Penayangan \\
\hline Toiletries & 249 \\
Makanan & 122 \\
Minuman & 121 \\
Peralatan Rumah tangga & 85 \\
Susu & 60 \\
Bumbu dapur & 54 \\
Kesehatan & 31 \\
Telekomunikasi & 15 \\
Peralatan telekomunikasi & 13 \\
Elektronik & 3 \\
Asuransi & 3 \\
Entertainment & 2 \\
Automotif & 2 \\
Permen & 2 \\
TV berlangganan & 2 \\
Website(berniaga,dll) & 1 \\
Aplikasi & 1 \\
\hline \multicolumn{1}{c}{ Total } & 766 \\
\hline
\end{tabular}


Berdasarkan Tabel 7, MNCTV pada Minggu menayangkan 249 iklan toiletries, 122 iklan makanan, 121 iklan minuman, 85 iklan peralatan rumah tangga, 60 iklan susu, 54 iklan bumbu dapur, 31 iklan kesehatan, 15 iklan telekomunikasi, 13 iklan peralatan telekomunikasi, 3 iklan elektronik, 3 iklan asuransi, 2 iklan entertaiment, 2 iklan automotif, 2 iklan permen, 2 iklan TV berlangganan, 1 iklan Website, 1 iklan aplikasi.

\section{Jenis-jenis Iklan Produk dan Frekuensi Iklan Disiarkan di Indosiar pada Sabtu}

Berikut adalah tabel jenis-jenis iklan dan banyaknya penanyangan di Indosiar pada Sabtu.

Tabel 8 Jenis-jenis Iklan dan Frekuensi Penayangan di Indosiar pada Sabtu

\begin{tabular}{lc}
\hline \multicolumn{1}{c}{ Jenis Iklan } & Frekuensi Penayangan \\
\hline Toiletries & 310 \\
Minuman & 104 \\
Peralatan rumah tangga & 103 \\
Susu & 101 \\
Makanan & 70 \\
Bumbu dapur & 31 \\
Kesehatan & 19 \\
Telekomunikasi & 17 \\
Permen & 11 \\
digital & 5 \\
aplikasi & 4 \\
bahan bangunan & 2 \\
Peralatan Telekomunikasi & 2 \\
Peralatan Automotif & Total \\
\hline \multicolumn{2}{c}{. } \\
\hline
\end{tabular}

Berdasarkan Tabel 8, Indosiar pada Sabtu menyiarkan 310 iklan toiletries, 103 iklan peralatan rumah tangga, 104 iklan minuman, 101 iklan susu, 70 iklan makanan, 31 iklan bumbu dapur, 19 iklan kesehatan, 17 iklan telekomunikasi, 11 iklan permen, 5 iklan digital, 4 iklan aplikasi, 2 iklan bangunan, 2 iklan peralatan telekomunikasi, 2 iklan peralatan automotif.

\section{Jenis-jenis Iklan Produk dan Frekuensi Iklan Disiarkan di Indosiar pada Minggu}

Berikut adalah tabel jenis-jenis iklan dan banyaknya penanyangan di Indosiar pada Minggu.

Tabel 9 Jenis-jenis iklan dan Frekuensi Penayangan di Indosiar pada Minggu

\begin{tabular}{lc}
\hline \multicolumn{1}{c}{ Jenis Iklan } & Frekuensi Penayangan \\
\hline Toiletries & 392 \\
Peralatan rumah tangga & 127 \\
Makanan & 106 \\
Minuman & 33 \\
Susu & 14 \\
Peralatan Automotive & 11 \\
Bumbu dapur & 10 \\
Kesehatan & 8 \\
\hline \multicolumn{1}{c}{ Total } & 701 \\
\hline
\end{tabular}

Berdasarkan Tabel 9, Indosiar menayangkan 392 iklan toiletries, 127 iklan peralatan rumah tangga, 106 iklan makanan, 33 iklan minuman, 14 iklan susu, 11 iklan peralatan automotif, 10 iklan bumbu dapur dan 8 iklan kesehatan. 


\section{Jenis-jenis Iklan Produk dan Frekuensi Iklan Disiarkan di SCTV pada Sabtu}

Berikut adalah tabel jenis-jenis iklan dan banyaknya penanyangan di SCTV pada Sabtu.

Tabel 10 Jenis-jenis Iklan dan Frekuensi Penayangan di SCTV pada Sabtu

\begin{tabular}{lc}
\hline \multicolumn{1}{c}{ Jenis Iklan } & Frekuensi Penayangan \\
\hline Toiletries & 253 \\
Makanan & 154 \\
Minuman & 82 \\
Peralatan rumah tangga & 63 \\
Bumbu dapur & 53 \\
Susu & 31 \\
Kesehatan & 31 \\
Peralatan Telekomunikasi & 15 \\
Telekomunikasi & 8 \\
Automotive & 7 \\
Permen & 4 \\
Digital & 4 \\
Bahan bangunan (semen,cat tembok) & 3 \\
Aplikasi (katok) & 2 \\
Penerbangan $\quad$ Total & 2 \\
\hline \multicolumn{2}{c}{} \\
\hline
\end{tabular}

Berdasarkan Tabel 10, SCTV pada Sabtu menayangkan 253 iklan toiletries, 154 iklan makanan, 82 iklan minuman, 63 iklan peralatan rumah tangga, 53 iklan bumbu dapur, 31 iklan susu, 31 iklan kesehatan, 15 iklan peralatan telekomunikasi, 8 iklan telekomunikasi, 7 iklan automotif, 4 iklan permen, 4 iklan digital, 3 iklan bangunan, 2 iklan aplikasi, dan 2 iklan penerbangan.

\section{Jenis-jenis Iklan Produk dan Frekuensi Iklan Disiarkan di SCTV pada Minggu} Minggu.

Berikut adalah tabel jenis-jenis iklan dan banyaknya penanyangan yang di SCTV pada

Tabel 11 Jenis-jenis Iklan dan Frekuensi Penayangan di SCTV pada Minggu

\begin{tabular}{lc}
\hline \multicolumn{1}{c}{ Jenis Iklan } & Frekuensi Penayangan \\
\hline Toiletries & 373 \\
Minuman & 123 \\
Susu & 106 \\
Peralatan rumah tangga & 83 \\
Makanan & 72 \\
Bumbu dapur & 35 \\
Kesehatan & 28 \\
Telekomunikasi & 22 \\
Permen & 11 \\
Peralatan telekomunikasi & 9 \\
Automotif & 8 \\
Aplikasi & 4 \\
Bahan bangunan & 4 \\
Bank & 1 \\
\hline \multicolumn{1}{c}{ Total } & 879 \\
\hline
\end{tabular}

Berdasarkan Tabel 11, SCTV pada hari minggu menayangkan 373 iklan toiletries, 123 iklan minuman, 106 iklan susu, 83 iklan peralatan rumah tangga, 72 iklan makanan, 35 iklan bumbu dapur, 28 iklan kesehatan, 22 iklan telekomunikasi, 11 iklan permen, 9 iklan peralatan telekomunikasi, 8 iklan automotif, 4 iklan aplikasi, 4 iklan bahan bangunan, dan 1 iklan bank. 


\section{HASIL DAN PEMBAHASAN}

Penelitian ini bertujuan untuk meninjau iklan-iklan yang disiarkan di televisi Indonesia. Berdasarkan data yang dipaparkan, dari 15 jam program yang ditayangkan pada Sabtu dan Minggu di empat stasiun televisi swasta, sepertiga (1/3) atau lima (5) jam merupakan iklan. Jumlah iklan yang ditayangkan lebih dari 700 iklan produk maupun iklan promosi di setiap stasiun televisi.

Dari 120 jam program dari empat stasiun televisi swasta (RCTI, INDOSIAR, MNCTV, dan SCTV) yang direkam, ditemukan bahwa iklan produk ditayangkan lebih banyak daripada iklan promosi. Penelitian ini juga menemukan bahwa iklan produk yang paling banyak ditayangkan adalah toiletries. Iklan toiletries adalah iklan produk yang mempromosikan barang-barang kebutuhan untuk kecantikan atau perawatan tubuh, misalnya adalah iklan pasta gigi, sampo, sabun, dan lainnya. Iklan toiletries ini ditujukan baik untuk anak maupun untuk dewasa.

Dari empat stasiun televisi, iklan makanan berada di peringkat kedua atau ketiga yang terbanyak ditayangkan di televisi Indonesia. Iklan makanan yang ditayangkan adalah biskuit, coklat, snack, dan lainnya. Kebanyakan iklan makanan yang ditayangkan merupakan makanan yang tidak sehat karena mengandung gula yang tinggi atau kalori yang tinggi. Temuan ini berbeda dengan temuan di negara-negara barat. Di negara barat iklan makanan adalah iklan yang paling banyak dipromosikan di televisi (Roberts \& Pettigrew, 2007).

Demikian halnya dengan iklan minuman. Iklan minuman termasuk iklan promosi yang banyak ditayangkan di keempat stasiun televisi swasta. Iklan minuman ini merupakan iklan minuman yang bersifat tidak sehat karena mengandung gula yang tinggi, seperti minuman bersoda, sirup, teh manis, dan lainnya.

\section{SIMPULAN}

Penelitian ini merupakan penelitian analisis konten yang dilakukan untuk melihat jenis-jenis iklan yang ditayangkan di empat televisi swasta di Indonesia. Dari hasil yang dipaparkan, empat televisi stasiun swasta di Indonesia menayangkan iklan yang cukup banyak. Dari lima belas jam program yang ditayangkan, sepertiga (1/3) atau lima (5) jam merupakan iklan. Iklan yang terbanyak ditayangkan adalah iklan toiletries yang merupakan iklan untuk perawatan tubuh. Kemudian disusul dengan iklan makanan, peralatan rumah tangga atau minuman.

Anak-anak di Indonesia ketika menonton televisi pada Sabtu dan Minggu terekspos dengan berbagai macam iklan, baik iklan yang ditujukan untuk mereka maupun untuk dewasa. Dari analisis konten, didapatkan bahwa televisi di Indonesia ditujukan kepada kaum dewasa, sehingga iklan yang disiarkan lebih berhubungan dengan iklan perawatan tubuh dan peralatan rumah tangga. Dengan banyaknya iklan yang ditayangkan di televisi, anak-anak di Indonesia rentan terhadap iklan yang ada di program televisi akhir pekan.

Anak-anak memerlukan dua keterampilan dalam memahami iklan. Keterampilan pertama adalah kemampuan untuk membedakan antara iklan dan program; dan yang kedua adalah kemampuan untuk memahami maksud dari persuasif iklan (Kunkel et al., 2004). Seorang anak mulai mengerti maksud persuasif iklan ketika mereka berumur tujuh atau delapan tahun namun mereka tidak sepenuhnya mengerti bahwa iklan bertujuan untuk memersuasi mereka untuk membeli (Oates et al., 2001). Ketika anak-anak tidak memahami maksud persuasif dari iklan, mereka mudah terpengaruh dengan iklan. Beberapa hasil penelitian sebelumnya menunjukkan bahwa beberapa dampak negatif dari iklan adalah obesitas dan sifat materialistis. Dengan banyaknya iklan yang disiarkan di akhir pekan, anak-anak di Indonesia rentan terhadap dampak-dampak negatif tersebut. 


\section{DAFTAR PUSTAKA}

Buijzen, M., \& Valkenburg, P. M. (2003). The unintended effects of advertising: A parent-child survey. Communication Research, 30, 483-503.

Carvel, J. (2000). TV ads have little effect on children. Diunduh 5 Januari 2013 dari http://www.guardian.co.uk/media/2000/nov/11/uknews

Departemen Komunikasi dan Informatika Republik Indonesia. (1997). Undang-undang Republik Indonesia nomor 32 tahun 2002 tentang penyiaran. Diunduh 5 Januari 2014 dari http://banten.kemenag.go.id/file/file/UUKIP/mths1327369030.pdf

Eriyanto. (2011). Analisis isi: Pengantar metodologi untuk penelitian komunikasi dan ilmu-ilmu lainnya. Jakarta: Kencana

Gorn, G. \& Goldberg, M. (1982). Behavioural evidence of the effects of televised food messages on children. Journal of Consumer Research, 9, 200-205.

Gunter, B., Oates, C., \& Blades, M. (2005). Advertising to children on TV. Content, impact and regulation. Mahwah, New Jersey: Erlbaum.

Halford, J. C. G., Gillespie, J., Brown, V., Pontin, E. E., \& Dovey, T. M. (2003). Effect of television advertisements for foods on food consumption in children. Appetite, 42, 221-225.

John, D. R. (1999). Consumer socialization of children: A retrospective look at twenty-five years of research. Journal of Consumer Research, 26(3), 183-213.

Kunkel, D. (2001). Children and television advertising. In D. G. Singer \& J. L. Singer (Eds.). Handbook of children and the media (pp. 375-394). Thousand Oaks, California: Sage.

Kunkel, D., Wilcox, B. L., Cantor, J., Palmer, E., Linn, S., \& Dowrick, P. (2004). Report of the American Psychological Association task force on advertising and children. Washington: American Psychological Association.

Lawlor, M. A. \& Prothero, A. (2003). Children's understanding of television advertising intent. Journal of Marketing Management, 19, 411-431.

Nairn, A., Ormrod, J., \& Bottomley, P. (2007, March). Watching, wanting and wellbeing: Antecedents and consequences of materialism in UK tweens. Paper presented at MidWest Materialism Conference, Champaign Urbana, Illinois, US

Oates, C., Blades, M., Gunter, B. (2001). Children and television advertising: When do they understand persuasive intent. Journal of Consumer Behavior, 1(3), 238-245.

Robertson, T. S. \& Rossiter, J. R. (1974). Children and commercial persuasion: An attribution theory analysis. Journal of Consumer Research, 1, 13-20. 